\title{
Prospects for the use of multipurpose engineering devices for wastewater treatment at industrial enterprises
}

\author{
Darya Ignatkina ${ }^{1}$, Alla Geraschenko ${ }^{1}$, Oksana Vlasova $^{1}$, and Victoria Telyatnikova ${ }^{2}$ \\ ${ }^{1}$ Volgograd State Technical University (VolgSTU), 400074, Volgograd, Russia \\ ${ }^{2}$ Volgograd State Social and Pedagogical University (VSSPU), 400005, Volgograd, Russia
}

\begin{abstract}
In this article, the authors highlight the issues related to the prospects for the use of multipurpose engineering and technical devices for wastewater treatment with the help of which it is possible to reach regulatory applicants for various pollutants of both organic and inorganic origin. The results of the development of the electrolyzer-adsorber combined device design, which makes it possible to carry out two sequential processes for obtaining substandard effluents, namely, electrochemical oxidation and sorption, are presented. Recommendations for the calculation for industrial use of a multipurpose engineering and technical installation developed by the authors are given. The results of the rational parameters' selection for the electrooxidation-sorption treatment of substandard waters are presented on the example of one of the food industry enterprises.
\end{abstract}

\section{Introduction}

When designing a sewerage system for industrial enterprises, in particular for the food industry, it is advisable to initially consider the issue of the technical possibility of reusing treated wastewater (WW), for industrial needs, excluding their discharge into the sewer network or water body.

In domestic and foreign practice, extensive experience has been accumulated in the application of WW cleaning technologies from various pollutants of both organic and inorganic nature, but, despite this, the selection of a rational and economically viable method for extracting contaminants from substandard waters of food industry enterprises remains an urgent task $[1,2]$.

Today, the use of WW electrochemical cleaning methods is promising, as compared to the traditional reagent and biological, it has a number of advantages: it allows to reduce the production area required for the equipment placement; makes it possible to correct the physicochemical properties of the processed liquid and extract valuable substances from it; greatly simplifies the technological scheme of cleaning and the operation of installations; provides a decrease in salt content in water; simplifies the automation of the work for all structures [2-4]. Moreover, in most cases, the method of electrochemical treatment of waste

\footnotetext{
* Corresponding author: viv_vgasu@mail.ru
} 
liquid is an environmentally friendly technology, due to the fact that, unlike reagent methods, secondary pollution of water is excluded with such components as anionic and cationic residues.

\section{Main part}

To achieve a deeper WW cleaning from organic and inorganic pollutants, the sorption method is used, which makes it possible to achieve the values of the required concentrations for a number of pollutants and reuse the purified water in the technological process of the enterprise [5-7].

The modern solution to the WW cleaning problem the food industry, due to the rise in the cost of water in the form of a production resource, must meet two main criteria:

1) ensuring the required quality of purified water for repeated use in the production process;

2) the second to have ecological and economic feasibility.

Review of literature on the problem of WW cleaning food industry enterprises showed that domestic and foreign scientists [1-7] are actively involved in the development of methods, devices and technologies for WW cleaning from organic contaminants, but, despite their abundance, the selection of the optimal and effective method for removing contaminants from WW of enterprises in the food industry remains an unresolved problem. Therefore, the improvement of known methods of purification and the creation of new multipurpose technical devices based on them is undoubtedly relevant, since it will allow to successfully solve not only the problem of high anthropogenic load on water resources, but also create the conditions for the use of substandard waters in the water circulation of the enterprise, as well as will significantly increase and ensure the environmental safety of the industrial facility as a whole.

To solve the above-listed problems, the authors of the article developed an engineering and technical device (Figure 1), where, as the main method for reducing the concentrations of pollutants that make up wastewater from food enterprises, to the values close to permissible concentrations (PC) the pollutants [7, 8], allowing the discharge of purified water into the sewer network of the city, the method of electrochemical oxidation was chosen, and the sorption method was chosen as a post-treatment. This will allow to reuse treated water for the technical needs of enterprises.

To assess the efficiency of the multipurpose engineering and technical device developed by the authors [9-10], research and selection of the main technological parameters of the structure was carried out on real WW, generated as a result of economic and production activities at a tobacco factory located in the territory of the Russian Federation. Average indicators of WW chemical composition, formed at the enterprise in question is presented in Table 1.

The principle of operation of a multipurpose engineering device developed by the authors is as follows:

1) after preliminary mechanical cleaning, the contaminated liquid from the storage tank is fed through the fitting (3) to the electrolyzer-adsorber, depending on the device performance, the pump sets the water column rise rate through the perforated electrode plates (9), where WW electrochemical treatment takes place;

2) upon reaching WW, that have undergone electrochemical cleaning at a predetermined level, the latter enter the first chamber of the two-chamber adsorber (10) filled with sorption material through the nozzle (11), then through the overflow hole (12), the water flows downward into the second chamber, where, when the predetermined level is reached, it is drained through the drain valve purified water (13); 
3) the flotation foam is discharged into the flotation sludge receiver using a scraper mechanism (15);

4) the flotation sludge is pumped for processing through a crane for pumping flotation sludge (23);

5) during the operation of the installation, the release of gaseous and fine-crystalline types of sediments inevitably occurs, the accumulated gases are discharged through the gas outlet pipe located in the electrolyzer cover (24), and the accumulated sediment is removed by flushing the device with a crane (1).

Table 1. Average indicators of WW chemical composition, generated at the tobacco factory for the period 2018-2020.

\begin{tabular}{|c|c|c|c|c|c|}
\hline $\begin{array}{r}\text { Selection } \\
\text { points of } \\
\text { WW } \\
\text { Samples }\end{array}$ & $\begin{array}{c}\text { No. } 1- \\
\text { Tobacco } \\
\text { workshop the } \\
\text { lines } \\
\text { ESS and } \\
\text { CRES }\end{array}$ & $\begin{array}{c}\text { №2 - } \\
\text { Tobacco } \\
\text { workshop }\end{array}$ & $\begin{array}{c}\text { No. } 3- \\
\text { Cigarette shop }\end{array}$ & $\begin{array}{c}\text { No. } 4- \\
\text { household } \\
\text { facilities }+ \\
\text { laboratory } \\
\text { block }\end{array}$ & $\begin{array}{l}\text { No. } 5- \\
\text { factory } \\
\text { exit }\end{array}$ \\
\hline indicators & Manufacturing & Household & Manufacturing & Household & Mixed \\
\hline $\begin{array}{l}\mathrm{BOD}_{\text {full, }} \\
\mathrm{mg} \cdot \mathrm{O}_{2} / \mathrm{dm}^{3}\end{array}$ & 1410 & 59 & 543 & 244 & 1856 \\
\hline $\begin{array}{l}\text { Suspended } \\
\text { substances, } \\
\mathrm{mg} / \mathrm{dm}^{3}\end{array}$ & 153 & 22 & 242 & 38 & 181 \\
\hline $\begin{array}{l}\text { Iron (total), } \\
\mathrm{mg} / \mathrm{dm}^{3}\end{array}$ & 0.12 & 0.18 & 0.23 & 0.15 & 0.2 \\
\hline Oils, $\mathrm{mg} / \mathrm{dm}^{3}$ & 5.7 & 1.69 & 2.78 & 4.3 & 5.9 \\
\hline $\begin{array}{l}\text { Ammonium } \\
\left(\mathrm{NH}_{4}\right) \\
\mathrm{mg} / \mathrm{dm}^{3}\end{array}$ & 44.11 & 8.08 & 48.35 & 12.77 & 32.5 \\
\hline $\begin{array}{l}\text { Petroleum } \\
\text { products, } \\
\mathrm{mg} / \mathrm{dm}^{3}\end{array}$ & 0.59 & 0.44 & 0.62 & 0.42 & 0.94 \\
\hline $\mathrm{AS}, \mathrm{mg} / \mathrm{dm}^{3}$ & 23.6 & 6.4 & 24.8 & 30,2 & 21.8 \\
\hline $\begin{array}{l}\text { Phosphates, } \\
\mathrm{mg} / \mathrm{dm}^{3}\end{array}$ & $<0.05$ & 0.66 & 0.85 & 0.14 & 0.56 \\
\hline $\begin{array}{l}\mathrm{COD}, \\
\mathrm{mg} \cdot \mathrm{O}_{2} / \mathrm{dm}^{3}\end{array}$ & 2455 & 97 & 824 & 373 & 2830 \\
\hline $\begin{array}{l}\text { Chlorides, } \\
\mathrm{mg} / \mathrm{dm}^{3}\end{array}$ & 69 & 59 & 64 & 58 & 59 \\
\hline $\begin{array}{l}\text { Sulphates, } \\
\mathrm{mg} / \mathrm{dm}^{3}\end{array}$ & 83 & 71 & 78 & 77 & 75 \\
\hline $\begin{array}{l}\text { Dry residue, } \\
\mathrm{mg} / \mathrm{dm}^{3}\end{array}$ & 920 & 160 & 782 & 162 & 834 \\
\hline $\begin{array}{l}\text { Calcined } \\
\text { residue, } \\
\mathrm{mg} / \mathrm{dm}^{3}\end{array}$ & 250 & 217 & 229 & 220 & 225 \\
\hline $\mathrm{pH}$ & 6.1 & 7.75 & 8.8 & 7.2 & 6.69 \\
\hline
\end{tabular}

The main technological parameters affecting the efficiency and energy intensity of electrooxidation-sorption treatment are: the initial concentration of contaminants in WW, 
$\mathrm{pH}$ aqueous medium, electrical conductivity of waste liquid, anode current density, time of electrical treatment, material of electrodes (anode and cathode) and distance between them, material and height of sorption charge, filtration rate, etc. [11-13].

Determination of the technological parameters' rational values for carrying out joint electrooxidation-sorption treatment, providing a stable mode of water purification up to PC for the previously indicated ingredients (Table 1), was carried out on real WW enterprises of the tobacco industry in the Russian Federation on a pilot plant (Figure 2), made on the basis of the developed device's structural drawings (Figure 1).
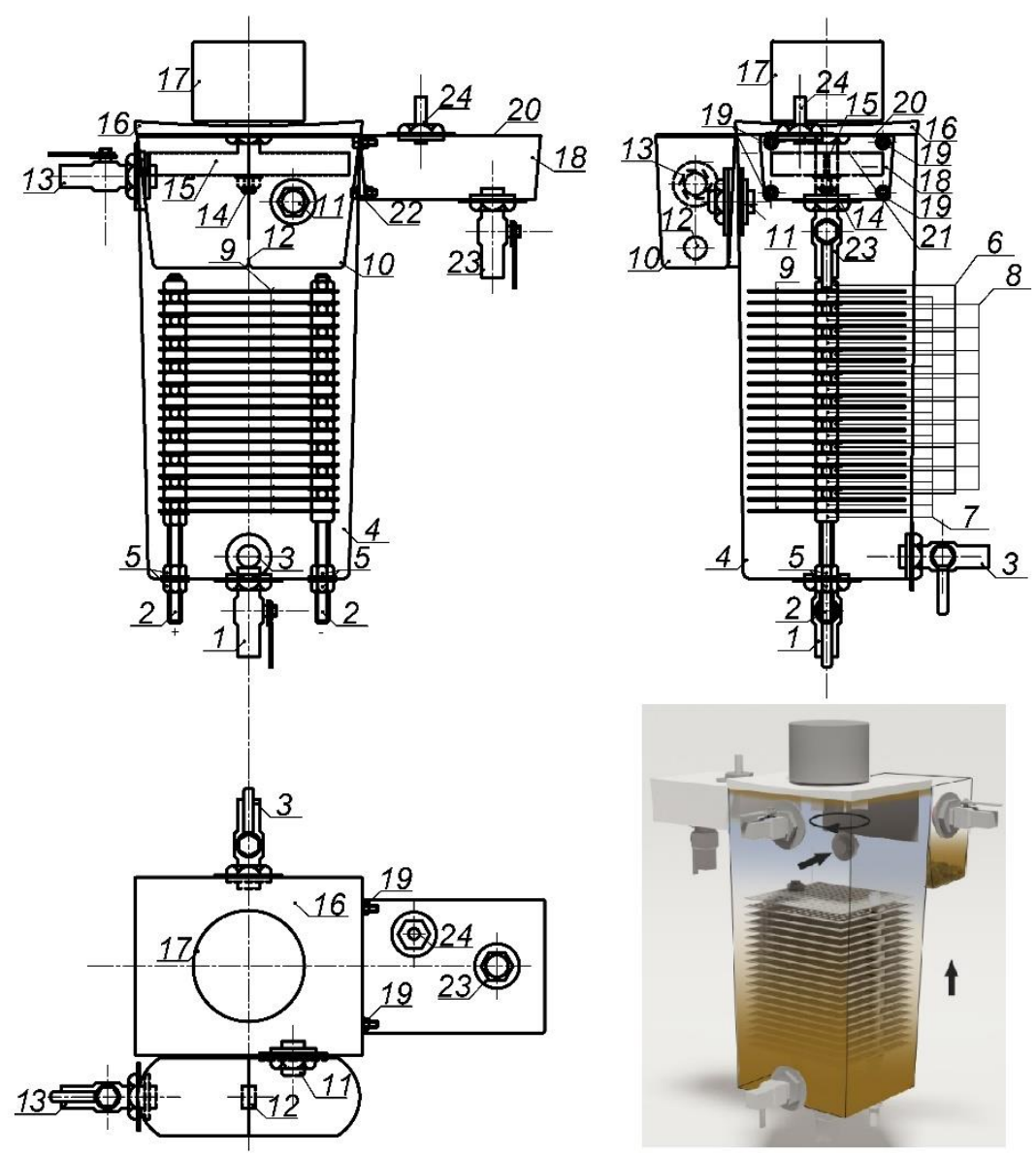

Fig.1. Multipurpose engineering device for wastewater treatment at food industry enterprises.

1 - valve for flushing the device; 2 - guide feeler pins; 3 - wastewater supply sleeve; 4 - device body; 5 - nuts for fastening contact guiding pins in the unit body; 6 - contact nuts for fastening the electrode plates; 7 - dielectric nuts for fastening the electrode plates; 8 - dielectric spacers; 9 - plates of electrolyzer electrodes; 10 - adsorber; 11 - nozzle for feeding into the adsorber wastewater that has undergone electrochemical treatment; 12 - overflow hole of the adsorber; 13 - drain valve for purified water; 14 - the shaft of the scraper mechanism; 15 - scraper mechanism made in the form of a paddletype mixer; 16 - cover of the electrolyzer-adsorber shell; 17 - reducer of the scraper mechanism; 18 receiver of flotation sludge; 19 - bolts of fastening to the electrolyzer-adsorber of the flotation sludge receiver; 20 - cover of the flotation sludge receiver; 21 - hole for feeding flotation sludge by means of a scraper mechanism made in the form of a paddle-type mixer located above the surface of the processed liquid into the flotation sludge receiver; 22 - connecting gasket; 23 - valve for pumping flotation sludge; 24 - gas outlet. 


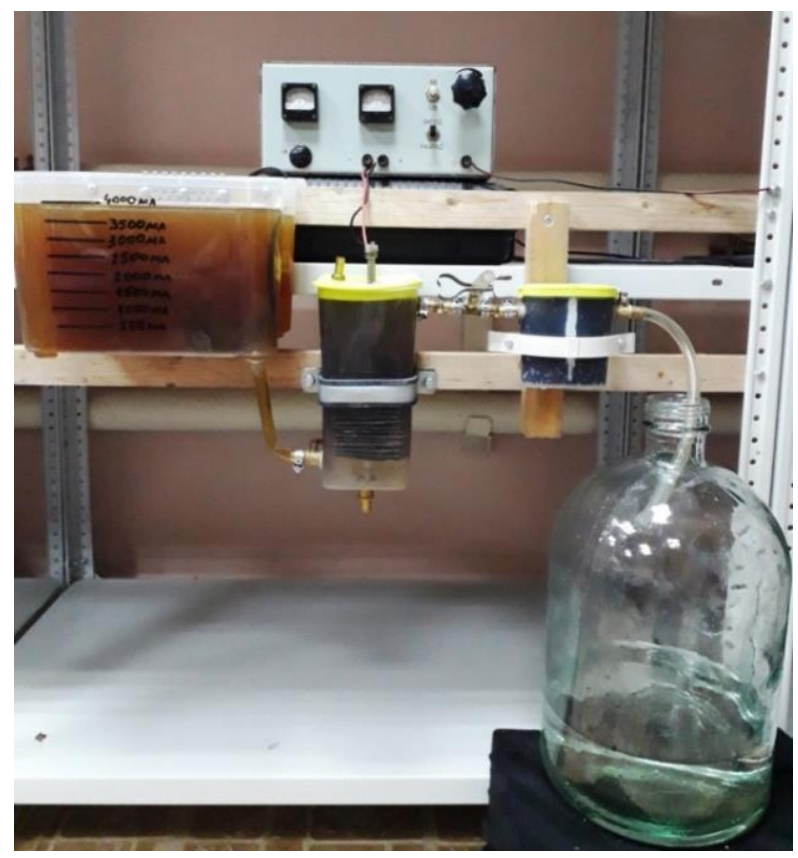

Fig. 2. Pilot installation of a multipurpose engineering device

The calculation for the industrial application of a multipurpose engineering and technical installation was carried out in the following sequence:

1) The volume of the electrolyzer chamber, was determined by the formula (1):

$$
V_{\kappa}=B \cdot L \cdot H, \mathrm{~m}^{3},
$$

where $B, L, H$ are width, length and height of the chamber, respectively, $\mathrm{m}$.

The height of the chamber was found by the formula (2):

$$
H=h_{1}+h_{2}+h_{3}, \mathrm{~m}
$$

where $h_{1}-i s$ the height of electrodes, $\mathrm{m}$;

$h_{2}$-is the solution height above the electrodes, m;

$h_{3}$-determines a sludge layer, $\mathrm{m}$.

2) Number of electrode plates $(n)$, placed in the installation width $(B)$, calculated by the formula (3):

$$
n=\frac{B-2 d+C}{P+C}, \mathrm{pc}
$$

where $d-i$ s the gap between the outer plates and the walls of the chamber, $d=50-100$ $\mathrm{mm}$;

$C$-is the distance between electrode plates, $C=3-15 \mathrm{~mm}$;

$P$ - is electrode plate thickness, $P=4-10 \mathrm{~mm}$. 
3) Active surface of electrodes ( $\left.S_{a}\right)$, was determined by the formula (4):

$$
S_{a}=(n-1) \cdot(L-2 d) \cdot h_{1}, \mathrm{~m}^{2},
$$

where $h_{1}-i$ s the height of electrodes, m;

$h_{2}$ - is the solution height above the electrodes, m;

$h_{3}-$ is a sludge layer, $\mathrm{m}$.

4) Amperage (i) in the electrolyzer was calculated according to the formula (5):

$$
i=I \cdot S, \mathrm{~m}
$$

where $I-i$ is the anode current density (found from the experiment), A/ $\mathrm{m}^{2}$;

$S$ - is the total area of the electrolytic chamber, $\mathrm{m}^{2}$.

5) Effective area (section) of the electrolytic chamber $\left(S_{\text {ef. }}\right)$, was determined by the formula (6):

$$
S_{\text {эф }}=S-S_{\text {эл. }}=L \cdot B-n \cdot(L-2 d) \cdot P, \mathrm{~m}^{2}
$$

where $S_{\text {эл. }}$ - area (section) of the chamber occupied by the electrodes, $\mathrm{m}^{2}$.

6) Effective area (section) of the electrolytic chamber $\left(S_{e f}\right)$, was found by the formula (8):

$$
S_{e f}=S-S_{e l .}=L \cdot B-n \cdot(L-2 d) \cdot P, \mathrm{~m}^{2}
$$

where $S_{e l}$. $-i s$ the area (section) of the chamber occupied by the electrodes, $\mathrm{m}^{2}$.

7) The overall dimensions of the adsorber were determined based on the volume of wastewater supplied for treatment and taking into account the data obtained as a result of constructing mathematical ones in terms of the WW sorption post-treatment efficiency at the tobacco factory in dynamic conditions on the filtration rate at different thicknesses of the sorbent layer, according to which the rational values of the considered parameter are in the range from $5 \mathrm{~m} 3 / \mathrm{h}$ to $6.5 \mathrm{~m} 3 / \mathrm{h}$ at the thickness of the loading layer of the granular composite sorbent (GCS) [14] equal to $0,8 \mathrm{~m}$.

Figure 3 shows the WW samples, which were selected after each stage of processing (mechanical, electrooxidation, and sorption) and subjected to laboratory analyzes according to the standard methods. The selection results of the rational parameters for the electrooxidative-sorption treatment of TF substandard waters are summarized in Table 2. 


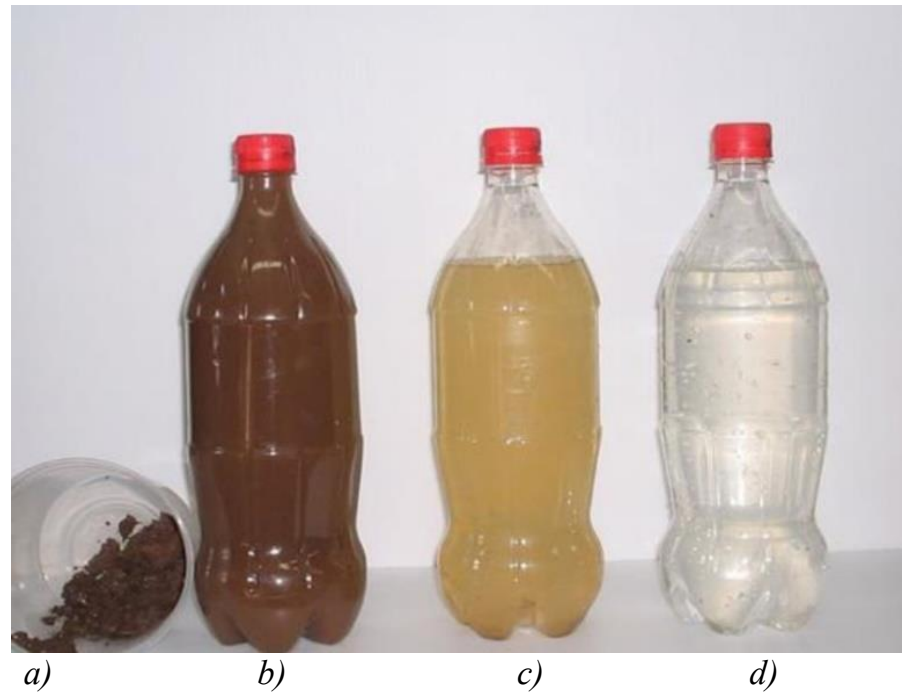

Fig. 3. WW sampling results after each cleaning step a) - sediment after mechanical cleaning and electrooxidation-sorption treatment; b) - after mechanical cleaning; $c$ ) - after electrooxidation; $d$ ) - after sorption.

Table 2. Technological parameters and efficiency of WW electrooxidation-sorption treatment for tobacco production

\begin{tabular}{|c|c|c|c|c|c|c|c|c|}
\hline \multicolumn{3}{|c|}{$\begin{array}{l}\text { Technological parameters of WW } \\
\text { electrooxidation-sorption treatment } \\
\text { for tobacco production }\end{array}$} & \multirow[b]{2}{*}{ 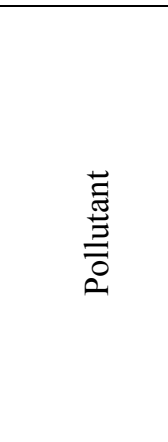 } & \multicolumn{3}{|c|}{$\begin{array}{l}\text { Changes in the } \\
\text { pollutant } \\
\text { concentration }\end{array}$} & \multicolumn{2}{|c|}{$\begin{array}{c}* * * \text { pollutant } \\
\text { MPC }\end{array}$} \\
\hline \multicolumn{2}{|c|}{ Parameter } & Value & & 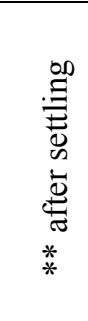 & 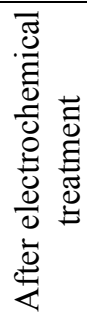 & 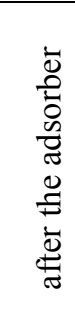 & 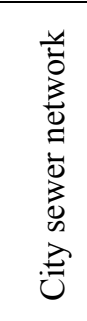 & 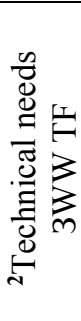 \\
\hline \multicolumn{2}{|c|}{$\begin{array}{c}\text { Installation } \\
\text { performance, } \mathrm{m}^{3} / \mathrm{h}\end{array}$} & 5 & \multirow{3}{*}{$\begin{array}{l}\text { Weighted } \\
\text { substances, } \\
\mathrm{mg} / \mathrm{dm}^{3}\end{array}$} & \multirow{3}{*}{$\begin{array}{l}87- \\
90\end{array}$} & \multirow{3}{*}{$\begin{array}{l}45- \\
51\end{array}$} & \multirow{3}{*}{$4-8$} & \multirow{3}{*}{$\begin{array}{c}41.0 \\
9\end{array}$} & \multirow{3}{*}{10} \\
\hline Water tem & rature, & $18-20$ & & & & & & \\
\hline $\mathrm{pI}$ & & $6.5-7.2$ & & & & & & \\
\hline \multicolumn{2}{|c|}{$\begin{array}{c}\text { Reagent } \\
\text { consumption } \mathrm{NaCl}, \\
\mathrm{g} / \mathrm{dm}^{3}\end{array}$} & 1.5 & $\begin{array}{c}\mathrm{BOD}_{\text {full }} \\
\mathrm{mg} \cdot \mathrm{O}_{2} / \mathrm{dm}^{3}\end{array}$ & $\begin{array}{c}1720 \\
- \\
1760\end{array}$ & $\begin{array}{l}138- \\
144\end{array}$ & $\begin{array}{l}12- \\
14\end{array}$ & $\begin{array}{c}34.4 \\
4\end{array}$ & 15 \\
\hline \multirow{2}{*}{$\begin{array}{l}\text { Electrode } \\
\text { material }\end{array}$} & $\begin{array}{c}\text { cathod } \\
\text { e }\end{array}$ & $\begin{array}{c}\text { нержавеюща } \\
\text { я сталь }\end{array}$ & \multirow{2}{*}{$\begin{array}{c}\mathrm{COD}, \\
\mathrm{mg} \cdot \mathrm{O}_{2} / \mathrm{dm}^{3}\end{array}$} & \multirow{2}{*}{$\begin{array}{c}2200 \\
- \\
2280\end{array}$} & \multirow{2}{*}{$\begin{array}{l}224- \\
235\end{array}$} & \multirow{2}{*}{$\begin{array}{l}21- \\
23\end{array}$} & \multirow{2}{*}{$\begin{array}{c}51.6 \\
6\end{array}$} & \multirow{2}{*}{25} \\
\hline & anode & ORTA & & & & & & \\
\hline \multicolumn{2}{|c|}{$\begin{array}{l}\text { Distance between } \\
\text { electrodes, mm }\end{array}$} & 3.5 & $\begin{array}{l}\text { Oils, } \\
\mathrm{mg} / \mathrm{dm}^{3}\end{array}$ & $\begin{array}{l}3.0- \\
4.5\end{array}$ & $\begin{array}{l}0.3- \\
0.41\end{array}$ & $\begin{array}{c}0.05 \\
- \\
0.09\end{array}$ & 10 & 0.8 \\
\hline
\end{tabular}




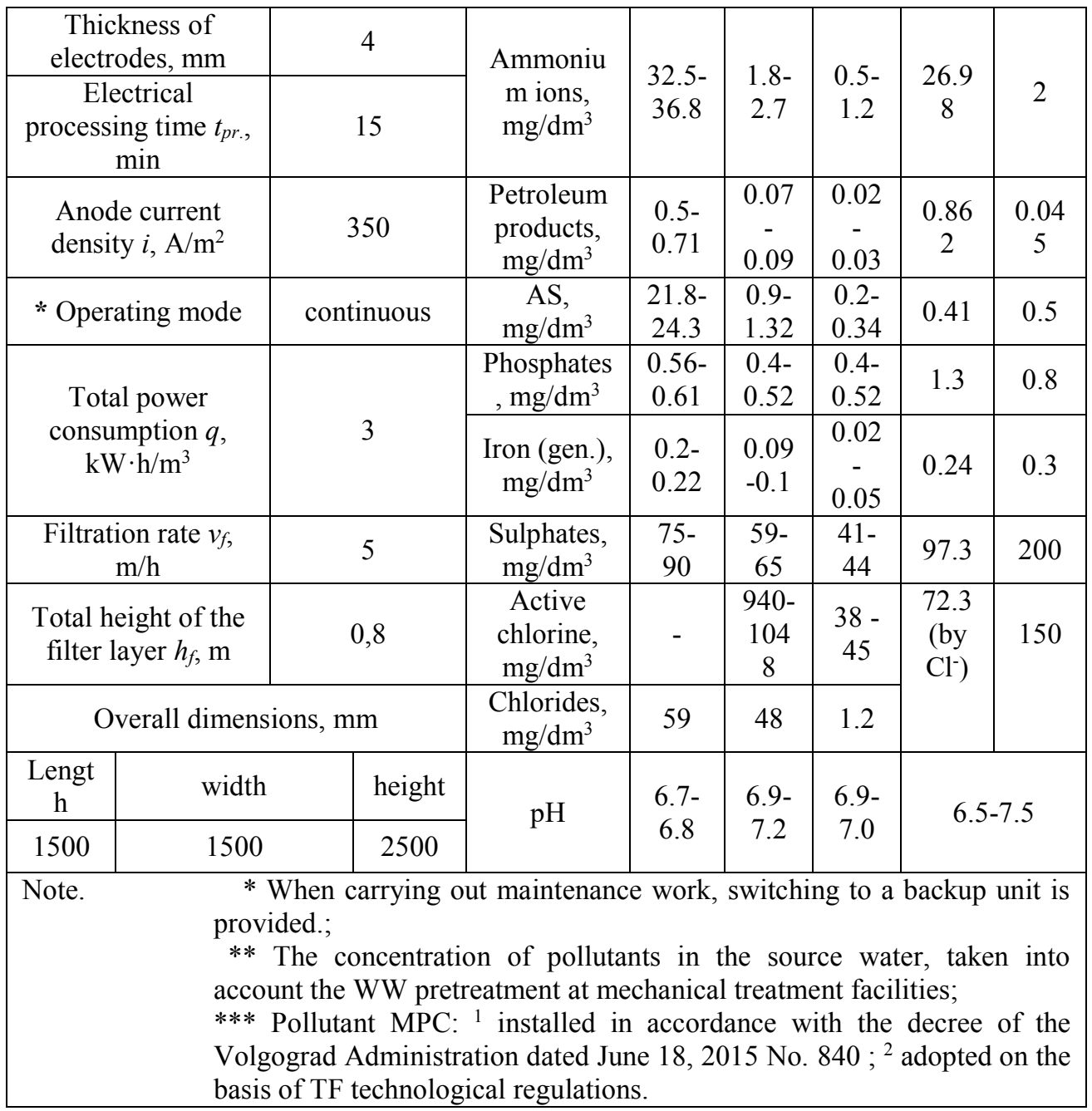

\section{Conclusion}

As it can be seen from Table 2 and Figure 3.34, the purification of the contaminated fluid by a preliminary mechanical method, and then by the method of electrochemical oxidation in combination with sorption post-treatment on a combined device, an electrolyzeradsorber, under properly selected processing conditions, makes it possible to improve the quality of purified water in terms of $\mathrm{BOD}_{\text {full, }}, \mathrm{COD}, \mathrm{AS}$, nitrogen-containing and suspended substances, as well as chloride ions up to the required standards, allowing the discharge of purified WW into the city sewer network and reused for the technical needs of the enterprise. This result is achieved due to the electrochemical oxidation of complex organic compounds, which, under the influence of an electric current, undergo destruction and transform into simpler substances, the subsequent removal of which occurs in a twochamber adsorber. 


\section{References}

1. Yu.V. Voronov, S.V. Yakovlev, Water disposal and wastewater treatment [Text]: textbook for universities (Publishing house of the Association of Civil Engineering Universities, Moscow, 2006)

2. Yu.S. Yusfin, L.I. Leontiev, P.I. Chernousov, Industry and environment (ICC "Akademkniga", M., 2002)

3. I.G. Krasnoborodko, S.V. Yakovlev, Technology of electrochemical water purification. (Stroyizdat, Department, Leningrad, 1987)

4. D.O. Ignatkina, A.V. Moskvicheva, E.P. Doskina, L.V. Olefirenko, V.A. Korobov, To the question of the electrooxidation method application for wastewater treatment of food industry enterprises, Innovative development of regions: the potential of science and modern education: materials of the II International scientific-practical conf. (Feb 7, 2019), Astrakhan state architectural and civil engineering university, Astrakhan, 246250 (2019)

5. D.O. Ignatkina, E.P. Doskina, E.V. Fedulova, V.A. Korobkov, On the issue of the choice of some technological parameters of electrochemical purification of multicomponent waste water on the example of tobacco industry enterprises, Technology of water purification (TECHNOVOD-2019), materials of the XII International scientific-practical conf., Moscow, October 22-23. 2019, Platov South Russian Polytechnic University (NPI), Novocherkassk, 291-297 (2019)

6. V.I. Ilyin, V.A. Kolesnikov, Water supply and sanitary engineering 2 (1), 21-24 (2005)

7. D.O. Ignatkina, A.V. Moskvicheva, A.A. Voytyuk, E.V. Fedulova, Saratov State Technical University named after Yu. A. Gagarin, Saratov, 582-586 (2019)

8. D.O. Ignatkina, A.P. Pozdnyakov, A.V. Moskvicheva, E.V. Moskvicheva, A.A. Voytyuk, Bulletin of the Volgograd State University of Architecture and Civil Engineering. Series.: Construction and architecture 1 (74), 88-96 (2019)

9. A.A. Voytyuk, D.O. Ignatkina, A.V. Moskvicheva, Patent 198750 the Russian Federation, MPK C02F 9/06 A device for wastewater treatment from multicomponent pollution for industrial enterprises, (2020)

10. D.O. Ignatkina, E.V. Moskvicheva, E.P. Doskina, A.V. Moskvicheva, A.A. Voytyuk, Water supply and sanitary engineering (WSE) 3, 36-44 (2018)

11. A.V. Moskvicheva, D.O. Ignatkina, E.V. Moskvicheva, D.N. Lebedev, A combination machine for industrial wastewater purification, IOP Conference Series: Materials Science and Engineering, The International Scientific Conference "Construction and Architecture: Theory and Practice for the innovation Development" (CATPID-2019) 01-05 October 2019, Kislovodsk 698, https://iopscience.iop.org/article/10.1088/1757-899X/698/5/055037. DOI:10.1088/1757-899X/698/5/055037.

12. D.O. Ignatkina, A.A. Voityuk, A.V. Moskvicheva, E.V. Fedulova, The design of a combined device for the treatment of highly concentrated waste water from an electrolyzer-adsorber, Technology of water purification (TECHNOVOD-2019): materials of the XII International scientific-practical Conference, Moscow, October 2223. 2019, Platov South Russian Polytechnic University (NPI), Novocherkassk, 265-271 (2019)

13. D.O. Ignatkina, A.A. Voityuk, A.V. Moskvicheva, E.V. Moskvicheva, I.V. Seliverstov, Patent 178983 the Russian Federation, MPK C02F 9/06 (2006.01) Device for wastewater treatment from multicomponent pollution, VolgSTU, (2018) 
14. D.O. Ignatkina, Development of a technology for purification of multicomponent wastewater from a tobacco industry enterprise, $\mathrm{PhD}$ Thesis summary, 05.23.04 (Penza, 2019) 